Anne White, UCL SSEES

In M. Nowicka and V. Šerbedžija (eds.), Migration and Social Remittances in a Global Europe (Basingstoke: Palgrave Macmillan, 2016).

This is the last pre-proof version of the chapter.

\title{
An inside-out approach to social remittances: linking migration and social change in Poland.
}

\begin{abstract}
To understand the impact of migration on sending countries it is worth first investigating social trends in those countries, then considering migration as one contributory factor to social change. This 'insideout' approach avoids over-stating the role of social remittances. Taking Poland as a case study, I identify examples of social trends - changing material aspirations and increasing levels of social trust and illustrate how aspirations link to migrants' experiences abroad which are transferred to 'stayers' back in Poland, but links between migration and trust are more complex. I further argue that literature on the impact of migration on receiving countries can aid understanding of how migration affects sending country populations, and that (if defined carefully) 'cosmopolitanism' is a helpful concept for understanding social change in Poland.
\end{abstract}

Anne White is Professor of Polish Studies at University College London School of Slavonic and East European Studies. Her publications on Polish migration include Polish Families and Migration since EU Accession (Bristol: Policy Press, 2011).

Introduction: In search of a more comprehensive approach to migration influences on social transformation in Europe

Broadly speaking, existing scholarship on the impact of migration on sending countries studies gaps left by migrants in the sending country (e.g. depopulation, brain drain, care drain) and ties established by migrants between receiving and sending countries (e.g. brain circulation, care chains, transnational parenting, economic and social remittances). However, there is also an argument for focusing attention on a third area: changing attitudes and behaviour among the general population in the sending country. Although migration research understandably focuses on migrants, to understand the connection between migration and social transformation in sending countries it is surely important also to adopt an 'inside-out' approach and study the recipients of those remittances as well as the agents of change. In keeping with much of the migration literature, my chapter refers to this population - among whom I include return migrants - as 'stayers'.

The focus of the chapter is mostly theoretical and methodological. It offers three interconnected ways to research the impact of migration on the general population of European sending countries. The first 
area of investigation is social trends in the sending country, as indicated by survey evidence. Identifying the most important aspects of social change, and reflecting on how these might be attributable to social remittances, alongside other determinants, provides pointers for where to search for evidence of social remitting. It simultaneously helps avoid overstating the role of migration in causing change. It is important to be realistic about migration's contribution to trends which happen for many reasons. The second objective is to study how remitting is perceived by stayers in local sending communities, and their reflections on how migration touches individual practices and attitudes. Thirdly, I consider the separate literature on the impact of migration on receiving countries - a body of research which largely focuses on stayers - to find clues towards a more nuanced understanding of the causes and nature of change in sending countries.

Since much of my article relies on evidence from my in-depth interviews in Poland, it is primarily concerned with migration-induced social change as a construct, not an objective and measurable 'reality'. I could not say, for example, that $20 \%$ of social change is caused by migration, but I can shed light on how migration influences people's identities and lives in Poland. I conclude that it makes sense to consider changing views among stayers in the sending society as a kind of cosmopolitanism, although this complements rather than invalidates the more commonly encountered proposition that social change in post-communist Europe is an aspect of (both endogenous and EU-induced) liberalisation processes.

My interest in social remittances is linked to a more general preoccupation with understanding migration impact as widely as possible. My basic research question is how to achieve such a comprehensive approach. At present, comprehensive analysis of migration impact is equally absent both with regard to immigration to receiving countries and emigration from sending countries. ${ }^{1}$ This is partly because of disciplinary divides among scholars working on receiving countries. It might be objected that there exists a copious literature on the relationship between migration and sending country development, which imparts a certain wholeness to the sending country scholarship. Much of this research is certainly wide-ranging and ambitious in scope (see e.g. De Haas 2012, Newland 2013). However, focusing on development in fact narrows the analysis. Because of their normative nature, developmental approaches ignore types of change which cannot easily be classified as good or bad. Moreover, research tends to focus on economic remittances. Insofar as it is concerned with social consequences of migration, it studies areas such as education and health, which are fundamental to development, but not so likely to be affected by social remittances in post-communist European sending societies which already have 'very high' human development indices ${ }^{2}$ and well-functioning

\footnotetext{
${ }^{1}$ Even Kapur 2010 - as far as I know, the author of the only full-scale monograph on the impact of migration on a particular country - is almost entirely concerned with the role of diasporas and returnees. His research question is ' $\mathrm{How}$ has international migration affected the political economy of India's development?', but migrants, rather than the political economy, are the main object of analysis. Slany and Solga (eds.) (2014), which translates as 'Social Consequences of PostAccession Migration by the Polish Population' is an impressive collection of research findings on different migration influences by Poland's leading migration scholars, but it resembles a patchwork rather than a synthesis.

${ }^{2}$ http://hdr.undp.org/en/countries
} 
educational and healthcare institutions. Here, the influence of migration is more likely to take place in the more elusive area of norms, values and behaviour, suggesting the need to 'bring culture back into migration debates', to quote Levitt and Lamba-Nieves (2011:2).

If one is interested in norms, values and changing behaviour in the broader society, as evidenced in sociological surveys, 'distinguishing migrants' specific influence, within the wealth of material and symbolic resources that circulate between and within nation-states, may be quite a hazardous task' (Boccagni and Decimo 2013:2). As De Haas points out in his survey of the literature on migration impact in Morocco:

\begin{abstract}
It is important to recognize that migration itself is constituent part of a complex set of radical social, cultural and economic transformations that have affected Morocco, as well as an independent factor in perpetuating and probably intensifying, magnifying and accelerating these processes at the local and regional levels. Migration is not only a factor explaining change, but also an integral part of change itself to the same degree as it may reciprocally enable further change. Other processes, such as improved education, increasing exposure to electronic media, improved infrastructure and tourism also play a key role in opening people's eyes to the wider world and helping to raise aspirations (2007:32).
\end{abstract}

Perhaps it is too bold to assume that the multiplicity of different local diffusion effects can be aggregated so that one can speak of influence on a national scale. Kapur, in his book on the impact of migration on India as a sending country, does consider primarily national level social remittances. However, this is in the very specific sense of how an internationally-educated elite has influenced India's politics and economy. By contrast, after more briefly considering a number of historical cases of local and regional social remittances, he concludes that these are relatively insignificant, because there is no evidence of 'systemic effects' (Kapur 2010: 145). In the early years of the Warsaw Centre of Migration Research, migration from Poland was viewed as an integral aspect of post-1989 socioeconomic transformation rather than a separate research area. ${ }^{3}$ However, scholars from the Warsaw CMR were careful to avoid using their ethno-surveys, conducted in different and individually unique Polish districts, to make too ambitious claims about developments on a national level. (See e.g. Frejka, Okólski and Sword 1998, Anacka et al 2011.)

One way of bridging the gap between local and national level change, and hence achieving the desired comprehensive approach, would be to look at regional data, and - given the paucity of regional level social surveys - specifically at regional migration cultures. I discuss the potential of this methodology in another article (White 2016b). A different approach to linking local and national data and disentangling migration from other globalisation-connected influences would be to take some clues from the already detailed receiving country literature, linking migration and changing social attitudes. This could suggest new avenues for sending society research, particularly employing the concept of cosmopolitanism. This is the approach adopted in the final section of this chapter. I do not wish to suggest that there are

\footnotetext{
${ }^{3}$ Information from Paweł Kaczmarczyk, Warsaw CMR.
} 
exact parallels between the impacts of immigration and emigration. However, since both types of impact are aspects of globalisation, it is hardly surprising if the research in both areas is complementary.

Polish survey evidence about changing values, attitudes and behaviour As already mentioned, my starting point is the changes which sociologists observe occurring in Polish society. In other words, rather than asking what migrants do which shapes Poland, I approach the question from the opposite direction, first mapping how Poland is changing, then asking how migration contributes to that change, looking at interactions between migrants and stayers and their outcomes. Channels of influence would include direct contacts between stayers and visiting migrants, and between returnees and other kinds of stayers, as well as virtual contact with migrants abroad, and stayers' observations of migrants' opinions and behaviour.

Social trends are relatively easy to chart in Poland, thanks to the abundance of high quality survey evidence. This, together with the very significant level of migration from Poland, make it an obvious case study. Moreover, although Poland has a long migration tradition, since 2004 the rate of migration has quickened dramatically, affecting all corners of Poland and all sections of Polish society (Slany and Solga 2014, Elrick 2008). Migration has therefore touched the lives of everyone. Moreover, because travel to other European countries has become significantly easier, visits to Poles living abroad seem to be very common, although rarely captured in statistics. The number of foreign residents has been growing, but by 2014 they still constituted only about 0.5\% cent of the Polish population (Stefańska 2015:7), hence contacts with foreign countries through migration acquire a particular significance.

With regard to social trends: major developments in the $21^{\text {st }}$ century include a tendency for Poles to become more secular and individualistic; some evidence of changing views on gender roles; increasing tolerance towards sexual and ethnic minorities; greater readiness to live and work alongside foreigners; and, on the whole, rising levels of social trust, usually defined in surveys as belief that 'most people' or 'strangers' can generally be trusted. ${ }^{4}$ One could describe the overall trend as being towards increasing liberalisation, although trends can also reverse, as happened in the crisis atmosphere of 2015, when attitudes towards refugees began to harden and when more voters (especially young people) chose far-right political parties.

The above-mentioned trends could be linked to Poland's experience as a post-communist country overcoming a specific historical legacy. This included collectivism (though this was weaker in Poland than in neighbouring countries) and low levels of social trust (though one has to be careful generalising about low trust in the country which gave birth to Solidarity). Other determinants of change include

\footnotetext{
${ }^{4}$ See e.g. Czapiński 2013; Grabowska 2013; Boguszewski 2013; Omyła-Rudzka 2015; Omyła-Rudzka 2016. For detailed discussion in English, see Golebiowska 2013.
} 
Poland's status as a $21^{\text {st }}$ century entrant to the EU, implying commitment to EU legislation, e.g. on equality and diversity; to rising levels of prosperity; and to specifically Polish trajectories such as the decline from the 1990s of the exceptional status of the Catholic Church, connected to its role as symbol of opposition to the communist regime. Equally, one could locate social change in Poland within global trends, such as changing popular culture and consumer practices, technological and commercial developments, increasing casualization of labour and, of course, migration (including for education).

Migration scholarship in Poland is well developed, including the beginnings of a literature on social remittances (reviewed in Slany and Solga 2014). However, mainstream Polish sociologists seldom consider migration-related determinants of change. They tend to look inside Poland for explanations, except in certain localities where the existence of transnational social spaces and the impact of migration is impossible to miss. ${ }^{5}$ At best, migration is seen as one social trend intertwining with others. This is equally true for overviews of social change in Poland, such as (Hamer 2009), which mentions mass labour migration once in passing (Hamer 2009:91) and for analyses of specific social phenomena. (Arcimowicz, Bieńko and Łaciak 2015), for example, seek to explain changing habits and customs in Poland as a result of media influence, but at the very end of the book acknowledge that their interviews showed experience of travel and work abroad to be more significant than media exposure (Arcimowicz et al.: 385-6). Scholars' apparent lack of interest in studying migration as a contributory factor to broader social change seems even more curious if we consider that the impact of internal migration on social trends is a recognised historical research topic: internal migration, urbanisation and industrialisation go hand in hand.

To research the impact of migration one would need first to identify some more specific opinions and forms of behaviour which contribute to the wider trends. For example, gender roles are changing as more couples share cooking, everyday shopping and childcare (Hipsz 2013:23-4), a development which might be somewhat connected to couples having to reorganise roles in connection with migration; and builders and cleaners are more respected (Cybulska 2013:6), perhaps reflecting the earning power of migrants doing these jobs. Greater willingness to accept foreigners marrying into one's family, or as colleagues, neighbours, priests and teachers, might stem the fact that more Poles know foreigners living in Poland. According to a CBOS survey, the figures were 25\% in 1999 and 48\% in 2015 (Kowalczuk 2015: 5, 3). Equally one might guess that more open attitudes derive from knowing foreigners abroad, through visits, education or work, although Kowalczuk does not consider this explanation. ${ }^{6}$ Polish exposure to more multi-ethnic societies abroad might also explain why, when asked whether 'it's good if a country is ethnically uniform', 42\% respondents disagreed in 2015, compared with 36\% in 2005 (Omyła-Rudzka 2015:10-11).

\footnotetext{
${ }^{5}$ For a fuller discussion, see White $2016 \mathrm{~b}$.

${ }^{6}$ The CBOS research report does not provide information on whether attitudes differed across any variables other than knowing foreigners resident in Poland.
} 
Exceptionally, given the general disregard of sociologists for migration influences, Domański suggested as early as 2005 that consumerism had begun to increase rapidly as a result of post-2004 migration (Domański et al 2005: 107). Evidence of rising aspirations in Poland is afforded by the fact that, for example, in answer to the question 'What will you be able to afford, what goods will you possess in 1015 years' time?', 34\% of Polish young people in 1990 expected to have a car and 50\% a house or flat; the figures were $60 \%$ and $77 \%$ by 2008 . However, the trend had been a fairly steady rise through the period 1990-2008, with no acceleration after EU accession in 2004, and of course there are many reasons why expectations should have risen during this period (Młodzież 2008: 16).

\section{Interview evidence about social remittances on a local level}

The discussion below draws on evidence from my recent ethnographic projects to find evidence of social remittances in Poland. My research focused successively on family migration; return; and the links between unemployment and migration. The research was conducted in 2007-13, mostly in three small towns (Grajewo, Sanok and Limanowa). My 144 interviews were with both return migrants and people who had never migrated. I also draw on my 42 interviews and many informal conversations with Polish migrants in the UK, as well as an opinion poll I commissioned in Poland in $2008 .^{7}$ The discussion which follows focuses on social remittances and two aspects of social change: rising aspirations, and increasing social trust. (For discussion of gender roles, see (White 2016b).)

By way of introduction, it is important to mention that interviewees' own constructions of reality need to be taken into account when considering how and why societies change. For example, frustratingly often, for the researcher of social remittances, interviewees appear convinced that Poland is unchanging. Not surprisingly, this was a particular refrain in small towns, but it was also illustrated in the following conversation with a couple who had lived in Bristol for several years, returned to Wrocław hoping to settle, but given up in frustration and come back to Bristol. They described their impressions of Wrocław upon their return to the city:

Dariusz: We just feel better here, more self-confident. In Poland we had to register everywhere, set up a bank account, get a doctor, etc. Lots of bureaucracy - we felt like foreigners.

Judyta: Here I know how to get things done, where to go. But not in Poland!

Dariusz: Polish bureaucracy is terrible, to get something done you have to go round ten different officials, whereas in the UK you just make a phone call.

Anne: Had Poland changed in your absence, or was it you?

Dariusz: I don't know, I think it was we who'd changed, because Poland couldn't totally change in just five years.

Judyta: In Poland it hadn't changed, we had changed, we had lived in a foreign country, we could make comparisons, things look completely different here from in Poland... I think we'd changed, our mentality, our way of thinking.

Dariusz: If we'd stayed in Poland and not gone to England

\footnotetext{
${ }^{7}$ For further details of the methodology see White (2011), White (2014), White (2016a). All translations from Polish sources in this article, and from my interviews, which were almost all in Polish, are my own.
} 
Judyta: We'd have thought that's the way it has to be. We made comparisons, we kept noticing it was this way here, and that way there.

(Interview in Bristol, 2011)

Such convictions could reflect stereotypes about Polish 'backwardness' (see e.g. Buchowski 2006 on self-orientalising discourses) but the couple's statement that if they had not lived in England they would have accepted Polish bureaucracy as normal suggests that, at least in this case, the cause Is simply heightened consciousness of their own new outlooks. The fact that Dariusz and Judyta had returned to one of the fastest developing cities in Poland - generally viewed as a beacon of progress is salutary reminder that interviewees (and voters) may disagree with standard interpretations of 'Polish reality'.

Rising material aspirations might seem a particularly obvious and convenient topic to investigate, using my 'inside-out' approach, for several reasons. Rising aspirations in Poland are both evident and easily measurable; moreover, the aspirations of migrant households in sending countries is a familiar topic in migration research and there is thus a base of comparative and theoretical literature. Migrants pick up new aspirations while they are abroad, and bring them home, encouraging stayers to raise their expectations, so this can be classed as a social remittance. Finally, it might seem that this should be an easy topic to discuss with informants, although in practice Polish interviewees often prefer not to seem greedy and downplay any suggestion of unwarrantedly high ambitions.

Expectations about what constituted a 'normal' standard of living were frequently expressed by my interviewees. For example, a nurse suggested:

In our own country, we should be able to earn at least enough to live on a decent level. I'm not talking about luxuries. But we need to be able to buy things. A TV or refrigerator or car is a basic necessity.

(Małgorzata, Grajewo 2008)

With regard to the television and refrigerator, 'normal' could be interpreted as 'normal in the late communist period'. However, considering a car to be a 'basic necessity' is definitely a post-communist phenomenon. (Car ownership in Poland rose roughly fourfold - fairly steadily - in the years 1989-2013 (Dmochowska 2014:74).) Like Galasińska and Kozłowska (2009), I found that interviewees often seemed convinced that 'normality' existed only in foreign countries. Stayers regularly commented on the 'easiness' of their friends' and relatives' lives in the West and told stories which illustrated how migrants spread ideas about what 'should' be affordable. For instance, I heard several accounts - in both Poland and England - of migrants going shopping in Poland with their non-migrant sisters, and being shocked at the price of 'basics'.

Recently I was in the shop [probably in Wrocław] with my sister buying basic things for the children and when she got home she thought she must have been cheated: she spent $800 \mathrm{zl}$ on one shopping bag's worth of stuff (Edyta, Bath, 2009) 
It is easy to see how such conversations - when items expensive in Poland are regarded by visiting migrants as 'basics' - shape aspirations among stayers.

As in many sending localities around the world, new housing built by migrants is the most evident marker of their success and one which was frequently commented upon by informants in Poland. More cautious interviewees said that houses might be built either with a Polish mortgage or migrant money or both, but others assumed a link between migration and housing. For example, Maria, commenting on her neighbourhood in Limanowa - notable for its splendid housing - said that 'since I arrived [in 2006] there have been lots of changes, building, they build the most beautiful houses' and claimed that on her street 'all' the fathers were working abroad to finance their houses. Other interviewees drew my attention to Słopnice, a village over the hill from Limanowa known until a few years ago for its underdevelopment and poverty and now remarkable for its abundance of attractive detached houses. Andrzej, for example, asserted that 'all these new houses here are built by migrants. Have you been to Słopnice? It's all built with foreign-earned money.'

Making one's house beautiful also seemed to be a social norm.

We have this mentality, around here, that everyone invests in their house. Some people in other places are less bothered about their dwellings and just get on with other things in their lives. While here, what you earn all goes into the house. To make it lovely, visually... In small places... everyone has to take into account what their neighbours say, and behave in a way they approve... Everyone knows each other very well, after all, and people have long tongues.'

(Ewa, village near Limanowa, 2013)

It was not simply the case that people went abroad to earn money to build houses, as migrants do across the world. This would be a migration motive rather than a social remittance. My interviews in the UK suggested that some migrants' aspirations had risen while they were abroad - they did not originally intend to earn money to buy housing in Poland, but when they saw that this might be feasible, they raised their expectations. This contributed to a house-building culture which was not new in south-east Poland but was intensifying in the new transnational social space between Poland and the West. In Poland, interviewees mentioned a particular boom of rising expectations in 2004-7 when the UK and Irish job markets were buoyant and the sterling-zloty exchange rate was favourable to Poles.

Eating out is a further indication of rising material aspirations. In Grajewo, a small town with high unemployment, full of return migrants and migrants' relatives who had made visits abroad, Anna described in 2012 how she had set up a new restaurant:

Anna: I had no idea what to do. But a friend of mine, my friends actually, we talked and talked, what the town needs. And that's what came up... Most of my clientele is upper class, middle upper class. No kids from school even though there are 
two schools near here. And mostly teachers. And parents, yes. My restaurant works... I'm not sure if that's about the money itself or the change of people's minds to go out. Because years ago it wasn't that way...

Anne: So why do you think people are changing their habits?

Anna: I think a lot of people travel. You know, outside Poland. To Europe, to the States. All over the world. And they see and they try to do the same here. And actually the standards of restaurants are changing as well. Because people want and demand different things and quality.

Migrants' materialism, and the effect this had on their families in Poland and the wider community, was also the object of open condemnation:

I'm opposed to lots of ways migation has a bad influence on young people. Because young people, parents show their children their love through money. Through money, and simply children have money for everything... Affection, families aren't the most important thing. And that leads to selfishness.. and children who are a bit poorer are humiliated by the ones who have money. So it has a thoroughly bad influence. On marriages, on adults, and the poison spreads to the children as well.

(Mieczysława, Sanok 2008)

The remainder of this section briefly considers another social phenomenon which scholars widely consider to be important in post-communist countries: the level of social trust. Low social trust afflicts the whole post-communist region and distinguishes it from much of Western Europe, especially Scandinavian countries where many Poles live and work. It seemed until 2012 that social trust was growing in Poland. According to CBOS national data, in 2004 only 17\% of Poles believed that 'generally speaking, you can trust most people"; by 2012, the figure had risen to 23\%, although it fell back to $22 \%$ in 2014 (Boguszewski 2014: 8). The figures are similar to those in World Values Survey Polish data for 2004 and 2012.

With regard to trust in strangers: my research suggests that communities with a strong tradition of migration to the USA, where there is a culture of migrating only with the help of trusted personal contacts are, thanks to recent experiences of EU migration, beginning to open up to the idea that internet job advertisements and recruitment agencies can also be trusted. I have interviewed migrants and relatives of migrants who made exactly this transition in their careers. In such places, this could be one factor contributing to an overall increase in social trust. One might also guess that the experience of living in more trusting societies could somehow rub off on Polish migrants abroad, making them feel more relaxed in everyday encounters with strangers. Marta, a young interviewee who had returned from Ireland and was now settled in Poland, spontaneously commented in 2011 that she had noticed Warsaw society becoming more trustful as a result of migration: 'The culture is different, people are more friendly in Ireland, they are open, they talk to you on the street, the bus stop and everywhere. Here, people are more reserved and not so helpful... [However,] I think that in Warsaw people are more friendly [than in other parts of Poland] because there are many young people who are not like that who know how it is like to be abroad and they bring some good types of behaviour from there'. 
It is interesting that Marta claimed that younger people were more open than their elders, given that both CBOS and WVS data suggest that young Poles are more distrustful. ${ }^{8}$ In fact one might well suppose that, rather than spreading trust, social remittances would consist of stories about the undependability of Poles abroad and therefore intensify distrust among Poles in Poland. A discourse of hostility among Poles abroad, other than close family and friends, has been commented upon by many other observers (e.g. (Eade et al 2007:36, Pietka 2011:149); my interviewees in Poland expressed identical views. For example, in Sanok, Grażyna, who had never migrated, commented:

Polish people, sometimes, well, as they say, it can be better to among foreigners. Because a Pole could be out to get you because he says 'you're earning more money and I'm getting worse money and you only just came'.

Iwona, who had lived in London before EU accession, but in 2008 was living in Sanok, likewise remarked:

It's so unpleasant that we Poles [abroad] don't know how to help one another, like other nationalities. There is so much envy among Poles - one person has a better job, the other one is worse off, but I'm not going to help you, l'd rather you were worse off.

The 'reality' of the situation is probably that Poles are more unhelpful where they are working in vulnerable jobs in the shadow economy and constrained to co-ethic networks, like Iwona, but not like Marta, with her well-paid legal job and circle of Irish acquaintances (see White 2011: 185-8).

Literature on receiving countries as a guide to social remittance research in sending countries

Discussions about the impact of migration on sending and receiving countries, as conducted by migration researchers, tend to focus on one or the other, but there is merit in considering the two side-by-side. For the purpose of understanding stayers this is useful because the general population of the receiving society is studied more often - the 'receiving country bias' referred to in the Introduction to this volume. The literature covers aspects of migrant experience which may directly feed into the nature of social remitting, such as the degree of trust returnees had experienced in their neighbourhoods while living abroad, linked to the social cohesion of localities in receiving countries. The receiving country research also has a focus on how beliefs about migrants and migration are interpreted and transmitted, and this is equally relevant for sending countries. Hence the findings of the receiving country literature could be often directly applied to understanding how sending country 'stayers' form their opinions as a result of living in transnational social fields.

Research areas in the receiving country scholarship include how and when migration moves up the political agenda, and becomes a topic of public concern in receiving countries (as paralleled in sending

\footnotetext{
${ }^{8}$ This not true in all societies: see e.g. World Values Survey data at http://www.worldvaluessurvey.org/wvs.jsp.
} 
countries, which, like Poland, may suddenly have to come to terms with the fact that they are experiencing a truly massive wave of emigration); hospitality, or, alternatively, hostility towards immigrants among different social groups; how and why different types of media shape opinions about the impact of migration, 'translating it into a political issue' (Mudde 2012:1-2); myths and myth-busting policies; trust and social cohesion in local areas with migrant populations, and the types of contact between newcomers and established residents which promote good neighbourliness; ethnic enclaves and connections between these and wider society. The receiving country literature pays attention to both the characteristics of individuals and the specificities of receiving localities - exactly the two topics which seem most important when researching social remittances in the sending country. Perhaps most significantly, research on the impact of migration tends to indicate that receiving society hostility to migrants is shaped overall by cultural fears more than economic ones (Hampshire 2013:23) and that, overall, educated, more urban and younger members of the receiving society are more likely to display cosmopolitan attitudes.

With reference to cultural fear, for example, just as populations of receiving countries become less trusting of newcomers because of myths spread about migrants, which seem to threaten their identity, so stayers in sending countries can become more fearful of migrating because of myths spread about alien culture in a receiving country. This is a negative social remittance.

They have a bit too much of that system regarding children. It's easy to lose your child in Norway. The minus of Norway is, well, they treat Poles well, but the problem with children, it's a bit different culture. Norway sees children as state property... You can easily lose a child if someone says something, and it's hard to get the child back. That's why my friends there haven't brought their children to Norway because they are afraid for them. Those foster families in Norway earn good money. That's why people are scared. Not the brave ones. That's the minus. More people would stay in Norway but they're all afraid about their children, however. Children are the most important thing, at least, definitely for Poles.

(Andrzej, return migrant, Limanowa 2013)

Also in Limanowa in 2013, Jerzy commented 'People live differently abroad. No one cares about anyone else or talks to them. But in Poland family ties are strong'. It is easy to see how such convictions (expressed by a return migrant) find fertile ground where they correspond with anti-Western messages given in some sermons and by some of the Catholic media, in parts of rural Poland where migration makes a real contribution to the local economy, and the 'threat' can only be perceived in cultural terms.

The media, politicians and to some extent also researchers in receiving societies are preoccupied with 'poor integration' and 'parallel lives': enclaves of cultural otherness. Perhaps it is not too fanciful to identify similar enclaves of return migrants, who (at least in their own eyes) have different ways of behaving from the majority sending society. This, for example, is how such a situation was perceived by Eugeniusz, who explained in 2012 how he had set up a forestry team near Grajewo with other return migrants, as an island of German working practices. 
When I was in Germany I got to know the technology, how work was organised. I brought those things back to Poland, to a new market. Because I came back here to work in 2000. Ah, I had unusual good luck because a few friends had [also] been able to work in German forests back then. And when they returned to Poland they worked for me. So I had enough experienced and useful people... People who knew what they were doing. They knew how to be careful. Working in Poland, it was the same. None of us, I or any of my employees, ever had an accident.

Eugeniusz backed up his account with a story about working for a Polish construction company in Białystok which made balconies not fit to carry weight. 'That's Polish mentality. You can't imagine it happening abroad. I learned a lot. Taking a more responsible approach to things.'

Eugeniusz, like Marta, had had positive experiences of working alongside local people while he was abroad, and, in accordance with the contact hypothesis, become more understanding of difference as a result (see e.g. Fonseca and McGarrigle, 2012). Willingness to see positive aspects of other cultures was then transmitted back to Poland, where, in Eugeniusz's case, he hosted and socialised with German hunter tourists. Although different in social background, place of residence in Poland and migration experience, both Marta and Eugeniusz could perhaps be seen as 'cosmopolitans'. As defined by Delanty (2012: 340), a cosmopolitan disposition is 'an orientation towards tolerance of diversity, recognition of interconnectedness and a general disposition of openness to others'. However, 'cosmopolitan dispositions are far from universal, and one of the key questions that the latest empirical research has sought to address is which individuals or groups are more likely to exhibit these dispositions and why' (Keating 2015:3). Mau et al (2008:2), writing about the settled general population in Germany, show that 'people with border-crossing experiences and transnational social relations are more likely to adopt cosmopolitan attitudes with respect to foreigners and global governance'. On the basis of their quantitative data about stayers Mau et al cannot explain the mechanisms whereby this happens, but Delanty (2012:349) convincingly suggests that it is learned through the reflexivity promoted by transnational social relations: 'the means by which individuals, groups, societies, etc. undergo changes in their self-understanding'. It seems entirely plausible that Marta, working in Warsaw, experienced a confluence of influences promoting cosmopolitanism: a city full of well-educated young people, many of whom had worked, studied or travelled abroad, and with a much higher proportion of foreign residents than other locations in Poland. However, whether or not returnees - even if they personally felt more open as a result of migration - perceived Poland as dynamic, increasingly cosmopolitan and receptive to social remittances also depended on and their social background and milieu. For example, Anna, the restauranteur with her upper middle class clientele, and Eugeniusz, the forester, constructed Grajewo very differently.

\section{Conclusions}

This chapter has discussed social remittances within the wider context of the impact of migration on developed sending countries. The case study was Poland, a country with a strong sociological tradition and abundant, chiefly quantitative evidence about contemporary social trends. The chapter argues that 
a comprehensive analysis of social remitting needs to explore the lives of stayers. In a globalizing world, migration cannot be the only determinant of social change. Therefore, before even analyzing how migrants transmit foreign ideas and practices to their countries of origin, it makes sense to consider how stayers' lives are already changing, and how social remittances might contribute to those changes alongside other channels of influence.

To aid in disentangling the various strands of influence, I suggested consulting the rich scholarly literature about the impact of migration on receiving societies. Research suggests that mass immigration has complex and opposite impacts in different localities and among different sections of the population, promoting both cosmopolitanism and xenophobia. Educated, more urban and younger members of the receiving society are more likely to display cosmopolitan attitudes, but attitudes toward strangers depend on the quality of contacts with the other, access to sources of good information and exposure to manipulation by the media and politicians.

Applying these insights to Poland as a sending country, one can readily see how and why receptiveness to social remittances varies among stayers in different locations and social groups. Overall, however, Poland's mass exposure to migration and foreign travel - if only vicarious for some - cannot fail to influence its development. Social trends as evidenced in statistics, changes which can be classed as liberalization of attitudes - and linked by sociologists to system transformation - can equally be viewed as cosmopolitan - and therefore linked to globalization, including exposure to social remittances. In fact, given Poles' generally suspicious attitudes both to politicians and the business elite, it seems to make more sense to view changes in their behaviour as being linked not to identification with system change but rather to greater awareness of alternative ways of thinking and behaving, whether derived from migration or other types of globalization influence. Cosmopolitan sociological approaches focus particularly on certain kinds of social indicators such as tolerance towards foreigners and acceptance of ethnic diversity (both shown to be increasing in Poland) or trust (which has also increased since EU accession). Both trends could be related partly to the influence of return migrants, providing those migrants have had positive migration experiences, including good contact with foreigners abroad. However, there is a multitude of other types of social change which are derive from heightened awareness of alternative ways of living, such as rising material aspirations among stayers in Poland, including eating out in restaurants. In-depth interviews provide invaluable evidence about actual behaviour and details of social change which may not always be readily apparent in the statistics, as well as illustrating how individuals reflect on difference, acquire cosmopolitan dispositions (or not) and view the potential for change locally. According to Delanty (2012: 342) 'the big question for cosmopolitan analysis is the challenge of explanation, namely how to explain major socio-cultural change entailing shifts in moral and political values'. Social remittances play a part in this process. 


\section{References}

Anacka, M. Jaźwińska, E., Kaczmarczyk, P., Kopczyńska, J., Łukowski, W., Mostowska, M., Napierała, J. and Okólski, M. (2011) Etnosondaże podejście do badania migracji jako procesu społecznego, in P. Kaczmarczyk (ed) Mobilność i migracje w dobie transformacji: wyzwania metodologiczne. Warsaw: Scholar.

Arcimowicz J., Bieńko M. And Łaciak B. (2015) Obyczajowość. Polska poczq̨tku XXI wieku-przemiany, nowe trendy, zróżnicowania. Warsaw: Żak.

Boccagni, P. and Decimo, F. (2013) Mapping social remittances. Migration Letters 10 (1): 1-10.

Boguszewski, R. (2013) 'Wartości i normy'. Warsaw: CBOS BS/111.

Buchowski, M. (2006) 'The Specter of Orientalism in Europe: from Exotic Other to Stigmatized Brother', Anthropological Quarterly, 79(3): 463-482

Cybulska, A. (2013) Prestiż zawodów. Research Report 164. Warsaw: CBOS.

Czapiński, J. (2013) Indywidualna jakość i styl życia, Diagnoza Społeczna 2013 Warunki i Jakość Życia Polaków - Raport, Contemporary Economics, 7.

De Haas, H. (2007) The impact of international migration on social and economic development in Moroccan sending regions: a review of the empirical literature. Working Paper 3. Oxford: Oxford University International Migration Institute.

De Haas, H. (2012) The Migration and Development Pendulum: A Critical View on Research and Policy. International Migration 50 (3): 8-25.

Delanty, G. (2012) A cosmopolitan approach to the explanation of social change: social mechanisms, processes, modernity. The Sociological Review 60 (2): 333-54.

Dmochowska, H. (ed) (2014) Polska 1989-2014. Warsaw: GUS.

Domański, H., Rychard, A. and Śpiewak, P. (2005) Polska jedna czy wiele? Warsaw: Trio.

Eade, J., Drinkwater, S. and Garapich, M. (2007) Class and ethnicity - Polish migrants in London. ESRC End of Award Report. Guildford: Universities of Surrey and Roehampton. 
Elrick, T. (2008) The Influence of migration on origin communities: Insights from Polish migrations to the West, Europe-Asia Studies, 60 (9): 1503-17.

Fonseca, M. and McGarrigle, J. (eds) (2012) GEITONIES Generating Interethnic Tolerance and Neighbourhood Integration in European Urban Spaces. Policy recommendations. Promoting interethnic coexistence, social cohesion and reducing anti-immigrant attitudes. Migrare Working Papers 7. Lisbon: Centro de Estudos Geográficos.

Frejka, T., Okólski, M. and Sword, K. (1998) In-depth studies on migration in Central and Eastern Europe: The case of Poland. New York and Geneva: United Nations.

Galasińska, A. and Kozłowska, O. (2009) Discourses of a 'normal' life among post-Accession migrants from Poland to Britain, in K. Burrell (ed.) Polish migration to the UK in the 'new' European Union: After 2004. Farnham: Ashgate: 87-105.

Golebiowska, E. (2013) The many faces of tolerance: attitudes towards diversity in Poland. London: Routledge.

Grabowska, M. (ed) (2013) Rodzina i jej przemiany. Opinie i diagnozy No. 26. Warsaw: CBOS.

Hamer, K. (2009) Polacy w ciągu dekady zmiany systemowej, in P. Radkiewicz and R. Siemieńska (eds), Społeczeństwo w czasach zmiany. Warsaw: Scholar.

Hampshire, J. (2013) The Politics of Immigration: Contradictions of the Liberal State. London: Polity Press.

Hipsz, N. (2013) O roli kobiet w rodzinie, in M. Grabowska (ed), Kobieta w rodzinie, w pracy, w przestrzeni publicznej. Warsaw: CBOS, series Opinie i diagnozy 25.

Kapur, D. (2010) Diaspora, Development and Democracy: the Domestic Impact of International Migration from India (Princeton University Press)

Keating, A. (2015) Are cosmopolitan dispositions learned at home, at school, or through contact with others? Evidence from young people in Europe. Journal of Youth Studies, DOI:

10.1080/13676261.2015.1072617

Kowalczuk, K. (2015) Przybysze z blizka i z daleka, czyli o imigrantach w Polsce. Research Report 93. Warsaw: CBOS. 
Levitt, P. and Lamba-Nieves, D. (2011) Social Remittances Revisited. Journal of Ethnic and Migration Studies 37(1): 1-2.

Mau, S., Mewes, J. and Zimmermann, A. (2008) Cosmopolitan Attitudes through Transnational Social Practices? Global Networks 8(1): 1-24.

Młodzież 2008 (2009) Warsaw: CBOS, series Opinie i diagnozy 13.

Mudde, C. (2012) The relationship between immigration and nativism in Europe and North America. Washington DC: MPI.

Newland K. (2013). What we know about migration and development. MPI Policy Brief 9. Washington DC: MPI.

Omyła-Rudzka, M. (2015) Tożsamość narodowa i postrzeganie praw mniejszości narodowych i etnicznych. Research Report 106. Warsaw: CBOS.

Omyła-Rudzka, M. (2016) Zaufanie społeczne. Research Report 18. Warsaw: CBOS.

Pietka, E. (2011) Encountering forms of co-ethnic relations: Polish community in Glasgow. Studia Migracyjne-Przegląd Polonijny, 1: 129-51.

Slany, K. and Solga, B. (eds) (2014) Społeczne skutki poaksecyjnych migracji ludności Polski. Warsaw: PAN.

Stefańska, R. (2015) Integration Policy and Activities in Poland. Interact Research Report 07. Robert Schuman Centre for Advanced Studies, San Domenico di Fiesole (FI): European University Institute.

White, A. (2011) Polish Families and Migration. Bristol: Policy Press.

White A. (2014) Polish return and double return migration. Europe-Asia Studies, 66 (10): 25-49.

White, A. (2016a) Informal practices, unemployment, and migration in small-town Poland. East European Politics and Societies and Cultures, 30 (2): 404-22.

White, A. (2016b) Social remittances and migration (sub)-cultures in contemporary Poland. 'On-line first', Central and Eastern European Migration Review. 